\title{
THE IMPACT WORK FAMILY CONFLICT ON PERFORMANCE: THE CASE OF MARRIED FEMALE NURSES
}

\author{
Wiendy Puspita SARI ${ }^{1 *}$ \\ Puteri Andika SARI ${ }^{2}$ \\ Reka Tantia AKTRISA ${ }^{3}$
}

\section{Received: January 2021 | Accepted: February 2021 | Published: April 2021}

Please cite this paper as: Sari, W.P., Sari, P.A., Aktrisa, R.T. (2021) The impact work family on performance: the case of married female nurses, Holistica Journal of Business and Public Administration, Vol. 12, Iss. 1, pp.11-26

\begin{abstract}
Work Family Conflict (WFC) is common problem for working women. The purpose of this study is to analyse the dimensions of WFC: WIF (Work Interference with Family) \& FIW (Family Interference with Work), and Performance of Working Women, and also to examine the influence of WIF and FIW on Performance of Working Woman partially and simultaneously. The research used survey method by giving questionnaires to 60 married female nurses from several Hospitals in Bandung. This study uses Partial Least Square (PLS) to analyse the relation between variables. The measurements of WFC are WIF \& FIW. The measurements of Performance are Quality, Quantity, Punctuality, Cost effectiveness, Supervision needs, Interpersonal impact, Communication (oralwritten), Job understanding / personal effectiveness, Teamwork, Achievement of performance results, Initiative / commitment. WIF has significant and negative impact on Performance of Working Women, the impact is about 46.7\% (moderate). FIW has significant and negative impact on Performance of Working Women, the impact is about $42.4 \%$ (moderate). WIF \& FIW has moderate impact on Performance of Working Women simultaneously, the impact is about $47.4 \%$.

Keywords: Work Family Conflict; Performance; Married Female Nurses
\end{abstract}

\footnotetext{
1 Sekolah Tinggi Ilmu Ekonomi Ekuitas, St. PH.H. Mustafa No.31, Bandung, Indonesia, wiendy.ps@gmail.com.

* Corresponding author.

2 Sekolah Tinggi Ilmu Ekonomi Ekuitas, St. PH.H. Mustafa No.31, Bandung, Indonesia, puteri.andika31@gmail.com.

3 Sekolah Tinggi Ilmu Ekonomi Ekuitas, St. PH.H. Mustafa No.31, Bandung, Indonesia, rekatantiaa@gmail.com.
} 


\section{Introduction}

Nowadays, working is common for women. Many women work because of several reasons, such as economics, self-actualization, status, etc. Egalitarianism has developed everywhere, so people believe men and women have the same right to work and pursue career. According to Indonesian Constitution (1945), Article 13, Paragraph 5 (2003), and Article 27, Paragraph 2, (2003), which discuss the topic of manpower, states that every citizen including women has the right to work. Competition and economic demands became some of the drivers of woman working. The latter supports the national economy by meeting the needs of the individual household. Nowadays, women work in many fields, such as medical, politics, culinary, military, economics and business, etc. In Indonesia, several housewives transform to woman entrepreneurs to fulfil their family needs. Women entrepreneurs prove their worth and value in economic and social arena and their way through (Gano-an, 2020).

Based on data that has been obtained from the official website of the Central Statistics Agency (BPS) from 2010 - 2018, the research shows an increase in the contribution of women's income each year. This can be described in the following table:

Table 1 Contribution of Indonesian Women's Income in 2010 - 2018 (Percent)

\begin{tabular}{ccc}
\hline No & Year & Revenue (\%) \\
\hline 1 & 2010 & 33.5 \\
2 & 2011 & 34.16 \\
3 & 2012 & 34.7 \\
4 & 2013 & 35.17 \\
5 & 2014 & 35.64 \\
6 & 2015 & 36.03 \\
7 & 2016 & 36.42 \\
8 & 2017 & 36.62 \\
9 & 2018 & 36.7 \\
\hline
\end{tabular}

Source: BPS, 2018.

The increase in the number of female employees gives understanding that economic encouragement is the reason why women come to work. However, for women who are already married and working, face a challenge. They need to balance their responsibilities between family and work. Work and family are two different realms for working women that make them facing dual roles. 
HOLISTICA Vol 12, Issue 1, 2021, pp.11-26

Working Women have two roles: as a mother \& wife that is obligated to take care of family and as employee that is obligated to do her work (Sari W. P., 2020). Work Family Conflict (WFC) has higher possibility to occur in working women than men (Sari W. P., 2018). In the past, especially in Indonesia, people believe that public role was for man and domestic role was for woman. Man was more expected to have masculine attributes (ambitious, aggressive, independent, brave, dominant, competitive, etc.) and woman was more expected to have feminine attributes (passive, obedient, caring, nurturing, tender, dependent, etc). This kind of understanding remains until now. Feminine Women who perform domestic role are more appreciated by society. It makes WFC still occur in working women, even though egalitarianism has developed everywhere, including Indonesia.

WFC is a manifestation of conflicts between two incompatible roles, roles at work and family (Flippo, 2005). It is difficult to fulfil two roles well, because demands from family and work often pull with one another. WFC has two types of conflict: Work Interfere with Family (WIF) and Family Interfere with Work (FIW) (Frone M. R., 2000). WFC (Work Interfere with Family \& Family Interfere with Work) has significant impact on job performance on married working women (Warokka \& Febrilia, 2015). Employee can experience stress, fatigue, decrease of job performance \& satisfaction, and commitment to the company because of balancing roles in family and work (Nart \& Batur, 2013). Various disciplines that studied WFC found that WFC are related to dysfunctional outcomes for the individual and organization (Efeoglu \& Ozcan, 2013).

Working women in any field have potential to experience WFC, especially who work in medical field. Doctors, Nurses, and other medical personnel's have difficulties in balancing roles at work and home because of high physical and emotional demands (Efeoglu \& Ozcan, 2013). Stress at work can affect family life in unexpected way and the other way around, and increase body and mind tension as the results (Pleck, Staines, \& Lang, 1980). Medical Personnel who experience stress have tendency to take care patients badly, both medically and psychologically. As result, WFC affect the quality of Medical Personnel \& treatments toward patients (Efeoglu \& Ozcan, 2013).

WFC Phenomenon also happen in Medical Personnel in Indonesia, especially in Married Female Nurses at Hospital in Bandung. Nurses work in shift system that is divided into: Morning shift (6am - 2pm), Middle shift (2pm - 10pm), Night Shift (10pm - 6am) (Sari W. P., 2020). Based on interview with several nurses at Hospitals in Bandung (15/09/2020), this kind of shifts system make them difficult to fulfil demands from dual roles, especially for nurses who have babies and toddlers. The night shift is the most unfavourable shift for married female nurses, because it makes them have less time with their families. It is also stressing and depressing for nurses to still give excellent services to the patients whatever their conditions are. They are obligated to keep their good attitudes and treat the patients nicely although they are in bad mood, feel exhausted, get scolded by superiors (head of nurses or doctors), or even experience unpleasant attitudes by patients. 
HOLISTICA Vol 12, Issue 1, 2021, pp.11-26

Pra survey about WFC and Performance are also conducted by giving questionnaires to several married female nurses who work at Hospitals in Bandung. The result is shown in the tables and chart below:

Table 2 Pra -survey of Work Interference with Family (WIF) on Married Female Nurses at Hospitals in Bandung, Indonesia

\begin{tabular}{|c|c|c|}
\hline Dimension & Indicator & $\begin{array}{c}\text { Percentage } \\
(\%)\end{array}$ \\
\hline \multirow[t]{3}{*}{ Time Based Conflict } & Work time disturbing family activities & $65 \%$ \\
\hline & $\begin{array}{l}\text { Time for work creates an imbalance with family } \\
\text { responsibilities }\end{array}$ & $58 \%$ \\
\hline & $\begin{array}{l}\text { Skipping family activities because of the time you have } \\
\text { to spend at work }\end{array}$ & $63 \%$ \\
\hline \multirow[t]{3}{*}{$\begin{array}{l}\text { Strain Based } \\
\text { Conflict }\end{array}$} & $\begin{array}{l}\text { Feel tired after coming home from work so do not } \\
\text { participate in family activities }\end{array}$ & $116 \%$ \\
\hline & It's hard to contribute to the family after work & $67 \%$ \\
\hline & Pressure at work causes stress to do things at home & $53 \%$ \\
\hline \multirow{3}{*}{$\begin{array}{c}\text { Behaviour Based } \\
\text { Conflict }\end{array}$} & Problem solving at work is not effective for home use & $69 \%$ \\
\hline & The nature of work is the opposite of home & $57 \%$ \\
\hline & $\begin{array}{l}\text { The nature of work does not help to be good parents } \\
\text { and wives }\end{array}$ & $35 \%$ \\
\hline
\end{tabular}

Source: processed data, 2020.

Table 1 shows that $65 \%$ married female nurses at Hospitals in Bandung experience WIF: $62 \%$ because of time based conflict, $79 \%$ because of strain based conflict, and $53 \%$ because of behaviour based conflict.

Table 3 Pra survey of Family Interference with Work (FIW) on Married Female Nurses in Hospitals in Bandung

\begin{tabular}{|c|c|c|}
\hline Dimension & Indicator & $\begin{array}{l}\text { Percentage } \\
\text { (\%) }\end{array}$ \\
\hline \multirow[t]{3}{*}{$\begin{array}{l}\text { Time Based } \\
\text { Conflict }\end{array}$} & $\begin{array}{l}\text { Time spent with the family interferes with work } \\
\text { responsibilities }\end{array}$ & $62 \%$ \\
\hline & $\begin{array}{l}\text { Time spent with family makes it difficult to do career- } \\
\text { worthy assignments }\end{array}$ & $62 \%$ \\
\hline & $\begin{array}{l}\text { Skipping work activities because of time spent on family } \\
\text { responsibilities }\end{array}$ & $61 \%$ \\
\hline \multirow[t]{2}{*}{$\begin{array}{l}\text { Strain Based } \\
\text { Conflict }\end{array}$} & $\begin{array}{c}\text { Thinking about family problems at work due to stress } \\
\text { from home }\end{array}$ & $69 \%$ \\
\hline & $\begin{array}{l}\text { Feeling stressed about family responsibilities makes it } \\
\text { difficult to concentrate on work }\end{array}$ & $55 \%$ \\
\hline
\end{tabular}


HOLISTICA Vol 12, Issue 1, 2021, pp.11-26

Restlessness in family life causes the ability to work to $53 \%$ be weak

Behaviour Based Properties that are applied at home are not effective if $69 \%$ Conflict applied at work Nature at home is the opposite of work $56 \%$

Solving problems at home is not the same as at work $55 \%$

Source: processed data, 2020

Table 2 shows that $60 \%$ married female nurses at Hospitals in Bandung experience FIW: $62 \%$ because of time based conflict, $59 \%$ because of strain based conflict, and $60 \%$ because of behaviour based conflict.

Figure 1 Performance of Married Female Nurses at Several Hospitals in Bandung, Indonesia

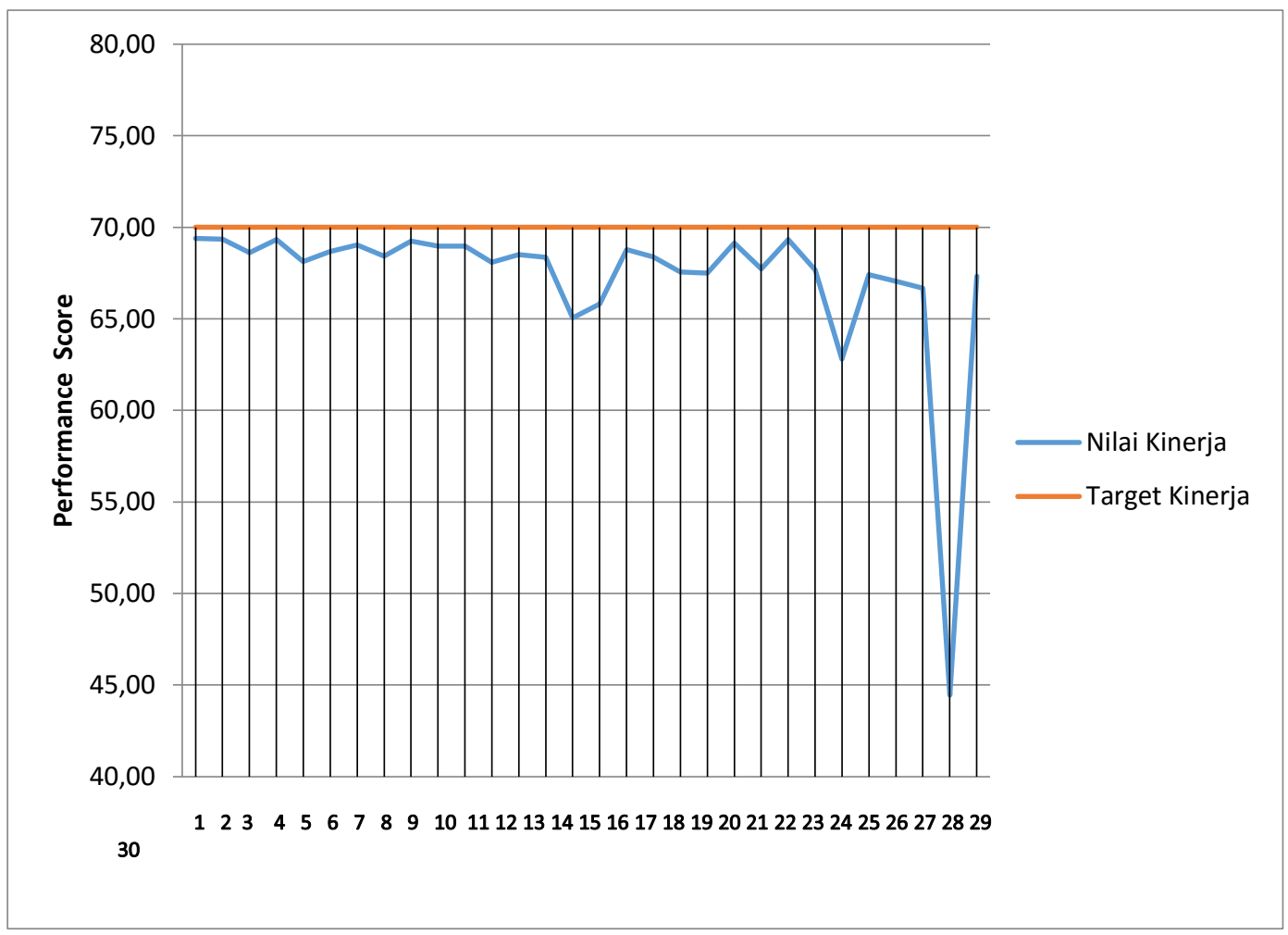

Source: Several Hospitals in Bandung, 2020

Figure 1 shows that 30 married female nurses from several Hospitals in Bandung have performance below standard. Based on interview with the nurses (15/09/2020), they said that it's hard equalized their responsibilities from two roles as nurse. It led them to experience stress, because in certain condition they need to prioritize one role and 
HOLISTICA Vol 12, Issue 1, 2021, pp.11-26

sacrifice the other. Medical personnel have high potential to get stress and poor health due to pressures at hospital (Jimenez, et. all, 2008). The performance of female nurses' decreases mostly because they have to choose between fulfil demands at work or family. (Sari W. P., 2020).

Therefore, this study wants to verify more about the impact of WFC on the performance of married female nurses. Based on the background of the research that has been presented, the formulation of the problem from the research of this scientific work is:

1. How is the condition of the Work Family Conflict on Married Female Nurses at Hospital in Bandung?

2. How influences Work Interference with Family (WIF) on the Performance of Married Female Nurses at Hospital in Bandung?

3. How influences Family Interference with Work (FIW) on the Performance of Married Female Nurses at Hospital in Bandung?

4. How influences Work Interference with Family (WIF) and Family Interference with Work (FIW) on the Performance of Married Female Nurses at Hospital in Bandung?

\section{Theoretical Framework}

\subsection{Job Performance}

Employee performance is the employee's contribution to achieving company goals or continuous improvement. There are several indicators in employee performance (Dessler, 2020), including the following:

1. Communication (oral-written): Gathering information and ideas, listening and looking for understanding.

2. Understanding of work/personal effectiveness: Demonstrate understanding and skills necessary for work effectiveness. Understand the job expectations and implement them according to responsibility. Responsible at work according to job procedures and policies. Acting as a resource on those who depend on it for help.

3. Teamwork: Maintain harmony and effectiveness of working relationships with colleagues and be consistent. Adapt to priorities changes. Build collaborative relationship with sharing information and resources.

4. Achievement of performance results: Complete tasks carefully, accurately, and on time so as to achieve the expected results. Determine attention to the goals and needs of the department and other departments that depend on the service and its performance results. Handling various responsibilities effectively, using working hours productively.

5. Initiative/commitment: Show personal responsibility when carrying out obligations. Offers assistance to support department and division goals and objectives, 
working with minimal supervision, according to the work schedule / attendance expectations for the position.

There are also six criteria to measure performance (Bernardin \& Russel, 2020), including: 1. Quality: Quality is the perfection degree of the process or results from activities or works.

2. Quantity: Quantity is the amount work result that is measured by numbers.

3. Timeliness: It is the level time to complete activities that is faster than time set, so can spend more time doing next activities.

4. Cost Effectiveness: It is maximizing the use of organizational resources to reduce loss and increase profit.

5. Monitoring Needs: Is the degree of responsibility of employee in doing his/her job properly without supervision.

6. Interpersonal Impact: It is the level of respect, collaboration and cooperation of employee towards his/her colleagues.

\subsection{Work Family Conflict}

Work Family Conflict is inter-role conflict which is caused by roles at work and family are equally incompatible (Greenhaus \& Beuthel, 1985). Which means a dual role conflict in a person that arises because of the pressure of the role of work into the family.

Work Family Conflict is classified into two types of conflicts, there are:

1. Work Interference with Family (WIF)

Work Interference with Family (WIF) is a conflict that occurs when work activities disrupt individual responsibilities in the family environment. WIF is result of excessive work demands that cause negative outcomes in family. For example, have meeting at work until late, make working women don't have time to do family activities with her children and husband (Sari W. P., 2020).

2. Family Interference with Work (FIW)

This role conflict can occur due to unfinished work or pressure in work that interferes with family needs. FIW is result of excessive family demands that cause negative outcomes at work. For example, working women prefer to accompany her children to study at home than attend office gathering after work. (Sari W. P., 2020).

Work family conflicts can be classified into 3 (three) dimensions (Greenhaus \& Beuthel, 1985), namely:

1. Time based conflict 
HOLISTICA Vol 12, Issue 1, 2021, pp.11-26

Conflict that is caused by time pressure, because the time held is used to fulfil certain roles resulting in difficulties to fulfil other roles.

2. Strain based conflict

Conflict that is caused by tension or pressure or confusion of roles by a role that interferes with other roles (work and family pressure).

3. Behaviour based conflict

That is the difficulty in changing behaviour resulting from a different role.

Figure 2 Theoretical Framework

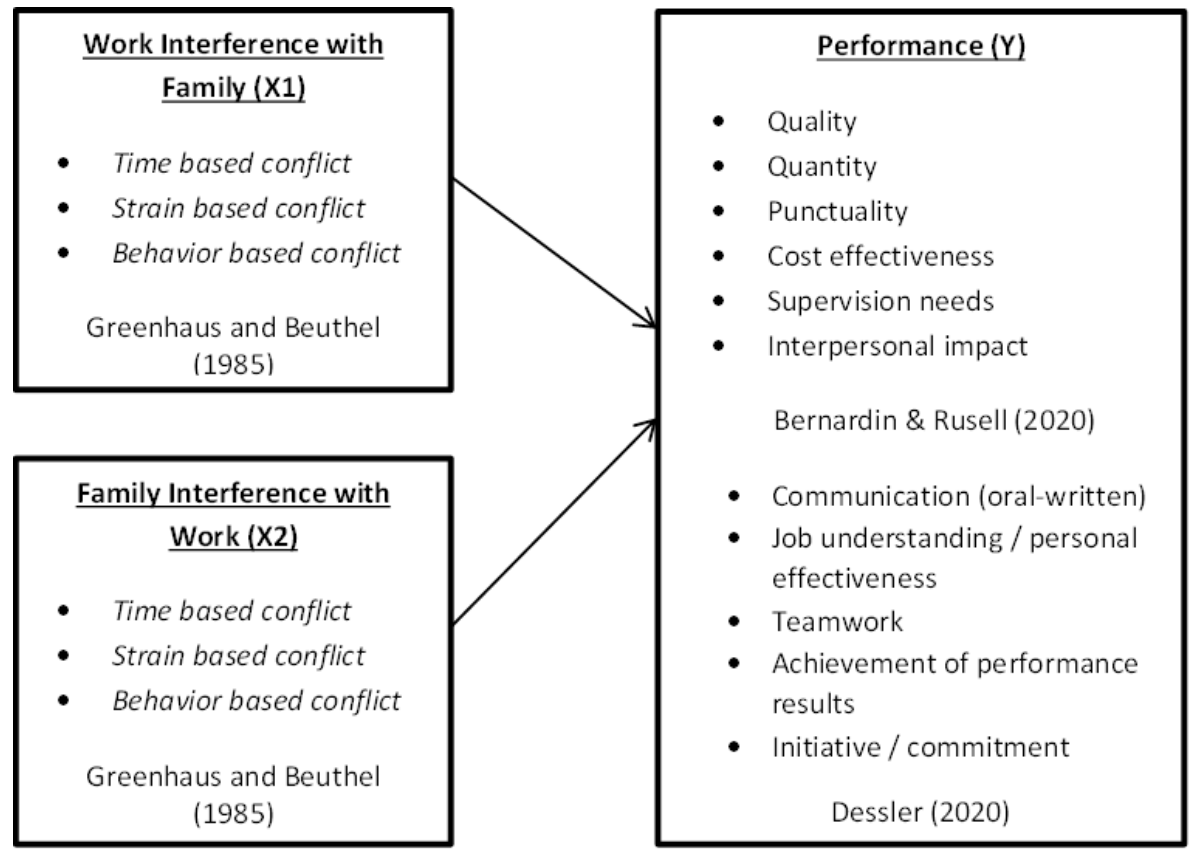

Source: Sari, 2020

\section{Research Method}

Empirical model of this study is:

$$
\begin{aligned}
Y & =P x 1 y X 1+\varepsilon 1 \\
& =P \times 2 y X 2+\varepsilon 2
\end{aligned}
$$

$\mathrm{X} 1$ refers to $\mathrm{WIF}, \mathrm{X} 2$ refers to FIW, and $\mathrm{Y}$ refers to Performance. Px1y is determined as path coefficient from $\mathrm{X} 1$ to $\mathrm{Y}$. Px2y is determined as path coefficient $\mathrm{X} 2$ to $\mathrm{Y}$. $\varepsilon 1$ is determined as epsilon $\mathrm{X} 1$ to $\mathrm{Y} . \varepsilon 2$ is determined as epsilon of $\mathrm{X} 2$ to $\mathrm{Y}$. This research gattered data by spreading 60 questionnaires to married female nurses from several 
Hospitals in Bandung. This study used Partial Least Square (PLS) is used to verify the impact between variables. PLS is a software modelling method which needs small number of samples (30-100 respondents) (Ghozali, 2008).

\section{Results}

4.1. Work Family Conflict: Work Interfere with Family (WIF) and Family Interfere with Work (FIW) on Married Female Nurses at Hospitals in Bandung

Figure 3 Continuum Line of WFC

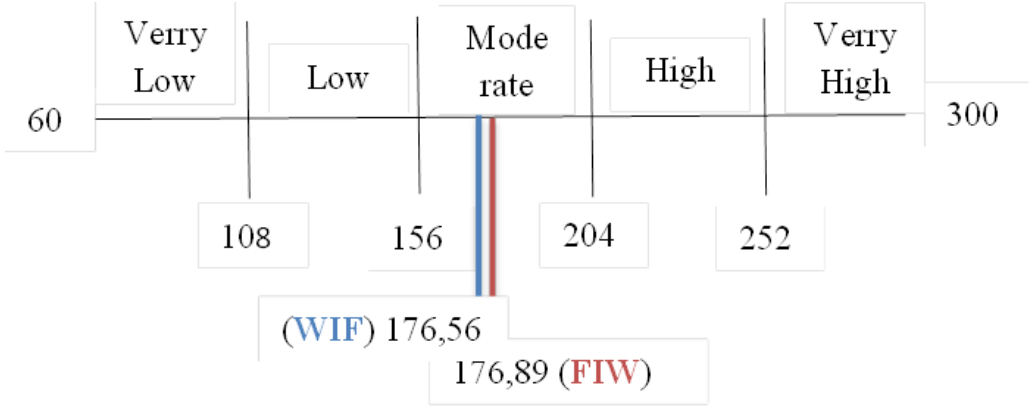

Source: processed data, 2020

Score of Work Interfere with Family (WIF) in Working Women (Married Female Nurses at several Hospitals at Bandung) is 176.59. It means level of WIF is moderate. Score of Family Interfere with Work (FIW) in Working Women (Married Female Nurses at Hospitals in Bandung) is 176.89. It means level of FIW is moderate.

\subsection{Partial Test}

\subsubsection{Impact of Work Interfere with Family (WIF) on the Working Women Performance (Married Female Nurses at Hospitals in Bandung)}

The Impact of WIF on Working Women Performance can be seen from the table below:

Table 4 Impact WIF on Working Women Performance

\begin{tabular}{ccccc}
\hline Original & $\begin{array}{c}\text { Sample } \\
\text { (O) }\end{array}$ & $\begin{array}{c}\text { Standard } \\
\text { Deviation } \\
\text { (STDEV) }\end{array}$ & $\begin{array}{c}\text { T Statistics } \\
(\mid \text { OS/STDEV } \mid)\end{array}$ & P values \\
\hline WIF -> Performance & -0.467 & 0.120 & 3.875 & 0.000 \\
\hline
\end{tabular}

Source: processed data, 2020 
HOLISTICA Vol 12, Issue 1, 2021, pp.11-26

The $t$ score is 3.875 and the coefficient correlation is -0.467 . It means that WIF has significant and negative correlation to Performance of Working Women. Impact WIF on Working Women Performance is $46.7 \%$. When WIF is high, Performance is low.

\subsubsection{Impact of Family Interfere with Work (FIW) on Working Women Performance (Married Female Nurses at Hospitals in Bandung)}

The Impact of FIW on Working Women Performance can be seen from the table below:

Table 5 Impact FIW on Working Women Performance

\begin{tabular}{ccccc}
\hline & $\begin{array}{c}\text { Original } \\
\text { Sample } \\
(\mathbf{O})\end{array}$ & $\begin{array}{c}\text { Standard } \\
\text { Deviation } \\
\text { (STDEV) }\end{array}$ & $\begin{array}{c}\text { T Statistics } \\
(\mid \text { OS/STDEV|) }\end{array}$ & P values \\
\hline FIW $->$ Performance & -0.424 & 0.121 & 3.498 & 0.001
\end{tabular}

Source: processed data, 2020

The $t$ score is 3.498 and the coefficient correlation is -0.424 . It means that FIW has significant and negative correlation to Performance of Working Women. Impact FIW on Working Women Performance is $42.4 \%$. When FIW is high, Performance is low.

\subsection{Simultaneous Test - Work Interference with Family (WIF) and Family Interference with Work (FIW) on the Performance of Married Female Nurses at Hospitals in Bandung}

The impact of WIF and FIW on Working Women Performance can be seen from the table below:

Table 6 Impact WIF \& FIW on Performance of Working Women

\begin{tabular}{ccccc}
\hline Relation & R square & F score & F Table & Conclusion \\
\hline $\mathrm{X} 1 \& \mathrm{X} 2->\mathrm{Y}$ & 0.474 & 25.710 & 3.159 & Accept H1 \\
\hline
\end{tabular}

Source: processed data, 2020

The F score is 25.710. It means that WIF and FIW simultaneously have significant correlation to Performance of Working Women. Working Women Performance is influenced by WIF and FIW about $47.4 \%$, and the rest is influenced by other factors.

The relation between variables and the main cause of the relations, can be seen in the figure below: 
Figure 4 Outer Model of WIF, FIW, and Performance

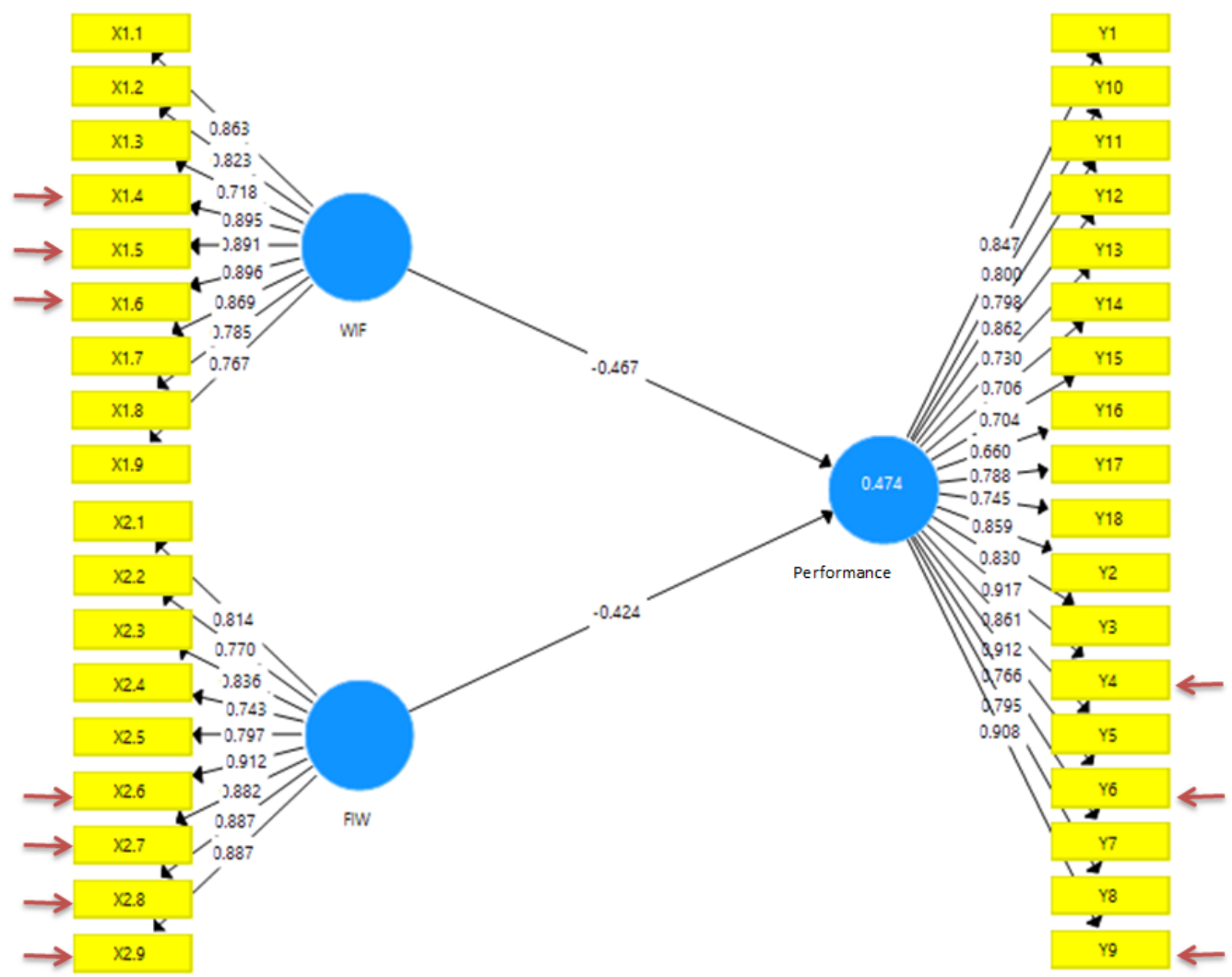

Source: processed data, 2020

From the table above, it can be concluded that WIF and FIW has impact on Performance of Working Women partially and simultaneously. WIF has significant and negative impact on Performance of Working Women. The impact is about $46.7 \%$ and categorized as moderate impact. The biggest cross loading factor of $X 1$ is $X 1-6$, then it follows by $X 1-4$ \& $\mathrm{X} 1-5$. It means that X1-6, X1-4, X1-5 are the biggest causes of impact WIF on Working Women Performances, and these three cross loading factors is classified in strain-based conflict in WIF. FIW has significant and negative impact on Performance of Working Women. The impact is about $4.4 \%$ and categorized as moderate impact. The biggest cross loading factor of X2 is X2-6, then it follows by X2-8, X2-9, \& X2-7. It means that X2-6, X2$8, X 2-9, \&$ X2-7 are the biggest causes of impact FIW on Performance of Working Women, and these cross-loading factors is classified as strain and behaviour-based conflict. 
HOLISTICA Vol 12, Issue 1, 2021, pp.11-26

Performance of Working Women is influenced by WIF and FIW simultaneously about $47.4 \%$ and the rest is influenced by other factors. The impact is categorized as moderate impact. The biggest cross loading factor is $Y-4$, then it follows by $Y-6$ and $Y-9$. It means that $Y-4, Y-6$, and Y-9 are the biggest consequences as the results of impact of WIF and FIW on working women performance.

\section{Discussion, and Conclusions}

\subsection{Impact of Work Interfere with Family (WIF) on the Working Women Performance (Married Female Nurses at Hospitals in Bandung)}

Work Interferes with Family (WIF) has significant, negative, and moderate impact on Working Women partially. Result of this study against the result of previous study by (Soomro, Breitenecker, \& Shah, 2018) who said that WIF has significant but positive impact to job performance. It is because:

\section{Time Based Conflict}

Married female nurses experience time-based conflict of WIF because of relatively long working hours, inflexible working hours and overtime work activities that make the individual unable to fulfil the family's demands optimally. Thus, causing conflict between work and family. With this conflict, the female nurse's performance was not optimal. This result is supported by (Byron, 2005) who said that time-based conflict in WIF cause by long and inflexible working hours and it made working women hard to fulfil family's demands.

\section{Strain Based Conflict}

Married female nurses feel experience strain-based conflict of WIF because of pressure in work place. Strain based conflict can trigger health problems (such as high blood pressure, anxiety, emotional exhaustion, even depression) that makes married female nurses perform well in their job. This result is supported by (Kinnunen, Feldt, Geurts, \& Pulkkinen, 2006) who said that the lack of ability in balancing work and family demands will influence the health and well-being of individual. Stress \& fatigue are some health issues because of balancing two incompatible roles, at work and in family (Nart \& Batur, 2013). Women also tend to get heavier work pressure than men (such as: discrimination based on sex, superwoman syndrome, devaluation of age in jobs that require certain physical appearance and skills), so that the consequences are often it happens that women do not get a wider opportunity both in planning and in career development (Almasitoh, 2011).

\section{Behaviour Based Conflict}

Married female nurses experience behaviour-based conflict of WIF because of characters, attitudes, and problem solving that applied at work cannot be applied at home. Sometimes the nurses behave at home like they behave at work. It considered misbehave by their family. For example, nurse is strict and tough towards the patients, so the patients will be obedient. But, she can strict and tough toward her husband and kids, because it 
HOLISTICA Vol 12, Issue 1, 2021, pp.11-26

will upset them. It's difficult for nurse to adjust herself to two different roles that against each other, then it grows to a conflict. This result of this study is supported by (Greenhaus \& Beuthel, 1985) who said that if a person cannot adjust to different roles, they will experience conflicts between roles in behaving in the work environment which is carried into the family environment.

\subsection{Impact of Family Interfere with Work (FIW) on Working Women Performance (Married Female Nurses at Hospitals in Bandung)}

Family Interferes with Work (FIW) has significant, negative, and moderate impact on Working Women partially. Result of this study is supported by (Warokka \& Febrilia, 2015) said that there is negative and significant influence of FIW on Job Performance. It is because:

\section{Time based Conflict}

Married female nurses experience time-based conflict of FIW because of time that is spent to do family's demands disturb work. For example, nurse cannot join hospital medical personnel gathering because she needs to take care her children, or she needs to go home earlier from work and bring papers to do at home because she needs to pick up her kid from school. This kind of conditions will affect work and non-work outcomes. Result of this study is supported by (Balmforth \& Gardner, 2006) who said that time-based conflicts of FIW will affect and have consequences that include non-work outcomes (life satisfaction, marital satisfaction, family satisfaction from employees) and work-related work results (job satisfaction, motivation, organizational commitment, turnover, attendance, job performance, career satisfaction and career success).

\section{Strain Based Conflict}

Married female nurses experience strain-based conflict of FIW because they tend to perform poorly at work while they have family issues, and responsibilities at family are overload and make them stress. For example, nurse has big fight with her husband or her kid, it makes her stress and does mistakes while working. Preparing husband and kids need before she goes to work to hospital early in the morning also can make her stress and lack of concentration while working. Result of this study is supported by (Greenhaus \& Beuthel, 1985) who said that thinking about family's issues while working, feeling stress about responsibilities as mother $\&$ wife and a nurse in the middle of her limitations can trigger strain-based conflict.

\section{Behaviour Based Conflict}

Married female nurses experience behaviour-based conflict because attitudes, characteristic, and problem solving at home cannot be applied at work. For example, nurse as a mother and wife has to be gentle towards her husband and kids, but has to be strict towards patients. Nurse as a mother and wife cannot make decision by herself, because the highest decision maker is her husband. At hospital, nurse should make 
decision towards patient, especially in urgent situation. Characters and attitudes at work and family are against each other, and most of the time make married female nurses trap in behaviour-based conflict in FIW. Result of this study is supported by (Greenhaus \& Beuthel, 1985) who said that characters and attitudes of working women at home are ineffective if it's applied in the workplace.

\subsection{Work Interference with Family (WIF) and Family Interference with Work (FIW) on the Performance of Married Female Nurses at Hospitals in Bandung}

WIF and FIW have significant and moderate impact on Working Women simultaneously. The biggest consequences as the results of impact WIF and FIW on working women performance are less concentration and ineffective at work, so the nurses keep making mistakes and wasteful in using medical tools and equipment. They also have tendency in showing unpleasant attitudes in team work because of their bad mood while having problems in their family (based on interview with respondents at 15/09/2020).

The result shows that the biggest cause of Work Interferes with Family (WIF) on Working Women are strain-based conflicts. Based on interview (15/09/2020) with respondents, married female nurses at Hospitals in Bandung feel exhausted and stress due to pressures at work, so they have no energy left to do family activities, hobby, or to do house chores. Result of this study is supported by previous study that said counterweighing dual roles in a finite time can cause health issues and poor work performance (Nart \& Batur, 2013).

The result shows that the biggest cause of FIW on Working Women are strain and behaviour-based conflicts. Based on interview (15/09/2020) with respondents, married female nurses said that family issues have weakened their ability to work. They perform poorly at work when they have problem at home. It considered as strain-based conflict. They also said that applied characters and attitudes at work toward their family, make their family uncomfortable and upset. It considered as behaviour-based conflict. Result of this study is supported by (Greenhaus \& Beuthel, 1985) who said that characters and attitudes of working women at home are ineffective if it's applied in the workplace. If a person cannot adjust to different roles, they will experience conflicts between roles in behaving in the work environment which is carried into the family environment.

\subsection{Conclusion}

This study shows that WIF and FIW on Working Women are at moderate level partially and simultaneously, especially in Married Female Nurses at Hospitals in Bandung. WIF has negative and moderate impact on Performance of Working Women. FIW has negative moderate impact on Performance of Working Women. Both of WIF and FIW also have negative and moderate impact on Working Women. Medical workers, especially women can develop WFC because shift system working hour and high pressure of work (Jimenez, 
et. all, 2008). It is because balancing dual roles, as mother and wife also as employee especially medical personnel is quite hard. Female nurses have to prioritize one demands over another because of clash between their work and family demands, and it affect their performances (Sari W. P., 2020).

From this study, it can be concluded that Hospitals have to mitigate the WIF (especially strain-based conflict) that is experienced by married female nurses or other married female medical personnel. Hospital needs to support recovery process of its workers by make Recovery Program to help its workers release fatigue and stress (Sari W. P., 2020). Hospitals management can design gathering programs or fun activities for medical personnel, such as recreation to nice places in or out of town. Hospitals also can provide medical personnel especially for nurses with sharing programs which is give them opportunity to share their burden at work and find solution for it. With this kind of programs, married female nurses and other medical personnel can release their stress and improve their performance.

On the other hand, families of married female nurses can be more supportive and cooperative towards their mothers \& wives who work as nurses. Support from family is the biggest fuel for working women. Family demand and lack of spouse support can increase the level of WFC in working women (Khursheed, Mustafa, Arshad, \& Gill, 2019). With support and cooperation from family, married female nurses can reduce FIW (especially behaviour-based conflict). By reduce the WIF and FIW, married female nurses can improve their performance. They can concentrate more on doing their job, so they will make less mistakes, not wasteful in using medical tools and equipment, and show better attitude in team work.

\section{References}

Almasitoh, Ummu Hany (2011). Stres Kerja Ditinjau dari Konflik Peran Ganda. PSIKOISLAMIKA, Jurnal Psikologi Islam (JPI), 8(1): 63-82.

Balmforth, Kelly, \& Dianne Gardner (2006). Conflict and Facilitation between Work and Family: Realizing the Outcomes for Organizations. New Zealand Journal of Psychology, 35(2): 69-76.

Bernardin, H John, \& Joyce E.A. Russel (2020). Human Resource Management: An Experiential Approach. New York: McGraw-Hill/Irwin.

Boyar, S L, CP Jr Maertz, \& A W Pearson (2005). The Effects of Work-Family Conflict and FamilyWork Conflict on Non-Antecedence Behaviours. Journal of Business Research, 58(7): 919925.

BPS. Sumbangan Pendapatan Perempuan Menurut Provinsi 2010-2018. 15 de 8 de 2018. Accessed September 1, 2020. http://www.bps.go.id

Byron, Kris (2005). A Meta-Analytic Review of Work-Family Conflict and Its Antecedents. Journal of Vocational Behaviour, 67(2): 169-198.

Dessler, Gary (2020). Human Resource Management, 16th Edition. Florida: Pearson, 2020.

Efeoglu, Efe, \& Sevgi Ozcan (2013). Work-Family Conflict and Its Association with Job Performance and Family Satisfaction among Physicians. Australian Journal of Basic Applied Sciences: 4348.

Flippo, M B (2005). Approaches to Work-Family Conflict in Organization. Journal of Sociological Studies, 10(2): 48-59. 
Frone, M R, M Russell, \& M L Cooper (1997). Developing and testing an integrative model of the work family interface. Journal of Vocational Behaviour, 50: 145-167.

Frone, M. R. (2000). Work-family conflict and employee psychiatric disorders: The national comorbidity survey. Journal of Applied Psychology, 82: 888-895.

Gano-an, J C. (2020). The Defining Moments of Business Success Among Women MicroEntrepreneurs: A Literature Review and Future Directions. Review of Behavioural Aspect in Organizations \& Society, 2(2): 95-112.

Greenhaus, J, \& N Beuthel (1985). Sources of conflict between work and family roles. Academy of Management Review, 10: 76-88.

Indonesian Constitution (1945). Articles 13 Paragraph 5 Year 2003. Indonesia: Indonesian Government.

Indonesian Constitution (1945). Articles 27 Pragraph 2 Year 2003. Indonesia: Indonesian Government.

Jimenez, B M, M Mayo, A I S Vergel, S Geurts, A R Munoz, \& E Garrosa (2008). Effects of WorkFamily Conflict on Employee's Well-Being: The Moderating Role of Recovery Experiences. IE Business School Working Paper.

Khursheed, Ambreen, Faisal Mustafa, Iqra Arshad, \& Sharoon Gill (2019). Work Family Conflict among Married Female Professionals in Pakistan. Management Studies and Economic System (MSES), 4(2): 123-130.

Kinnunen, U, T Feldt, S Geurts, \& L Pulkkinen (2006). Types of work-family interface: Well-being correlates of negative and positive spill over between work and family. Scandinavian Journal of Psychology, 47: 149-162.

Nart, S, \& O Batur (2013). The relation between work-family conflict, job stress, organizational commitment, and job performance: A study on Turkish primary teachers. European Journal of Research on Education, 2(2): 72-81.

Pleck, J H, G L Staines, \& L Lang (1980). Conflicts Between Work and Family Life. Monthly Labour Review, 103(3): 29-32.

Sari, W P. (2018). Work Family Conflict, Fear of Success, and Organizational Commitment in Working Women. HIKARI Ltd, 4(2): 71 - 82.

Sari, Wiendy Puspita (2020). Work Family Conflict, Recovery Experience, \& Employee's Well-Being in Working Women (Case Study of Nurses in Inpatient Departement at Hospitals in Bandung). HOLISTICA-Journal of Business and Public Administration, 11(1): 124-138.

Soomro, Aqeel Ahmed, Robert J Breitenecker, \& Syed Afzal Moshadi Shah (2018). Relation of Work Life Balance, Work-Family Conflict, and Family-Work Conflict with The Employee Performnace-Moderating Role of Job Satisfaction. South Asian Journal of Business Studies, 7(1): 129-146.

Warokka, Ari, \& Ika Febrilia (2015). Work Family Conflict and Job Performance: Lesson from Southeast Asian Emerging Market. IBIMA Publishing Journal of Southeast Asian Research: 1-14. 